\title{
Management of Soft Tissue Injuries in the Maxillofacial Region
}

\author{
Abhay Datarkar and Shikha Tayal
}

\subsection{Introduction}

Soft tissue injuries are one of the most commonly encountered injuries in head and neck region and present especially in the emergency department or surgical casualty. They can be isolated soft tissue injuries, or injuries having concomitant skeletal trauma. The frequent facial soft tissue injuries include simple lacerations, abrasions, contusions, bites, avulsions, and burns. These injuries are complicated by presence of vital anatomical structures like vessels, ducts, nerves, and muscles. Presence of foreign debris and hematoma further complicates the soft tissue injuries. The face is a region of high esthetics and functional importance. Hence, there are many factors that help to manage such injuries.

Factors that guide facial soft tissue injury management are:

(i) Recognition of nature of the injury-Helps in logical treatment planning that ultimately results in better esthetic and functional outcomes.

(ii) Extent of injury-Many facial soft tissue injuries that are relatively minor are treated in emergency department by the oral and maxillofacial surgeons. These wounds are managed by thorough cleaning, irrigation, debridement, primary suturing, and cleaning whenever needed. More complex wounds require special intervention by taking the patient into operation theatre and reconstructing using various grafts and flaps.

(iii) Timing of the injury-Any type of injury, by default, should be attended at the earliest to maximize the prognosis. The bottom line of many past and present literature is that the wounds of face and scalp should be

Disclosure: Authors have no financial conflicts to disclose.

\footnotetext{
A. Datarkar $(\varangle) \cdot$ S. Tayal

Department of Oral and Maxillofacial Surgery, Government Dental College and Hospital, Medical College Premises, Nagpur,

Maharashtra, India
}

primarily closed as soon as they are seen and as long as active infection is not present.

To achieve this, the surgeon needs to understand the etiopathogenesis, surgical anatomy, biomechanics of tissue wound, biology of wound healing, and the art of soft tissue repair.

\subsection{Etiology}

The most common etiology of facial soft tissue injuries varies according to the age, sex, and geographical distribution of the population. Facial soft tissue trauma tends to occur in certain areas of the head depending on the causative mechanism. It typically includes the T-shaped area that includes forehead, nose, lips, and chin, followed by the occiput and anterior temporal areas.

(a) Falls are by far the most common cause, accounting for $48-51 \%$ of the injuries $[1,2]$. This etiology has a trimodal distribution. The first peak is $2-3$ years, when toddlers begin to walk and fall into objects. There is smaller peak during the second and third decades and then a steady rise after age of 50 years. Alcohol consumption is a major factor for soft tissue injuries due to fall between 30 and 50 years. Medical comorbidities such as epilepsy are also the causative factor for falls in old age group.

(b) Non-fall impacts. Approximately $16 \%$ of facial soft tissue trauma is the result of a non-fall impact with structural element such a door, wall, or window frame. Other collisions with furnishings such as tables also counted. These types of injuries peak in children younger than 5 years. The common areas include the forehead, nose, and anterior temples.

(c) Assaults account for 16-32\% of facial soft tissue injuries [1]. The assaults are most commonly caused by fists, kicks, and blunt instruments. The injuries due to assault occurs more frequently among young men on left side of face. Alcohol consumption is a factor in two-thirds of these patients. 
(d) Road traffic accidents cause 6-13\% of facial trauma [2] where soft tissue injuries may occur alone or in combination with other fractures. The peak incidence is seen in young men at 15-24 years of age [3]. Impact from steering wheel, dashboard, and windshields results in most lacerations.

(e) Sporting injuries account for about $8 \%$ of facial soft tissue trauma [1], commonly occurring in young men. The forehead, nose, and teeth are the most likely areas to be injured. Concomitant facial fractures like nasal fractures, avulsive teeth injuries, and mandibular fractures are also common among these group of patients.

(f) Others include occupational injuries, bites from humans or animals, and other miscellaneous causes. Occupational injuries [3] account for 5\% of facial trauma and are primarily seen in young men. The risk of dog bites is higher for children aged 5-9 years and decreases with age. The frequency of facial injuries is highest in children younger than 4 years, in whom nearly $65 \%$ of dog bite injuries involve the face. In adults, it is about $9 \%$. Most dog bite injuries are from dogs known to person or occur near home. These injuries typically involve the cheek, lips, forehead, and nose.

\subsection{Classification of Soft Tissue Injuries}

Soft tissue injuries can be classified into multiple categories:

\section{(A) Based on mechanism of injuries}

(I) Mechanical or physical injuries:

- When injury is caused due to blunt force:
1. Abrasions

2. Contusions

3. Lacerations

- When injury is caused due to sharp force:

1. Incised wounds

2. Chop wounds

3. Stab/punctured wounds

(II) Thermal injuries:

- Due to excessive cold: e.g., frostbite

- Due to moist heat: e.g. burns and scald wounds

(III) Chemical injuries: Due to corrosive acids and alkalis

(IV) Miscellaneous: Electricity, lightning, etc.

(V) Explosions: Blast injuries

\section{(B) Legal classification}

1. Simple - soft tissue injuries without much tissue loss and can be managed conservatively. Heals rapidly without any permanent deformity.

2. Grievous injuries-described under Section 320 of Indian Penal Code as any injuries that endanger life and cause severe disfigurement or deformities like permanent hearing loss, vision loss, and severe head injuries. Tooth fracture or tooth loss following a blow in an interpersonal violence is also considered a grievous injury and penalized by the court of law. These injuries heal slowly and incompletely.

3. Dangerous - the grievous injuries that endanger life immediately after impact (Box 49.1).

\section{Box 49.1 Classification of Soft Tissue Injuries}

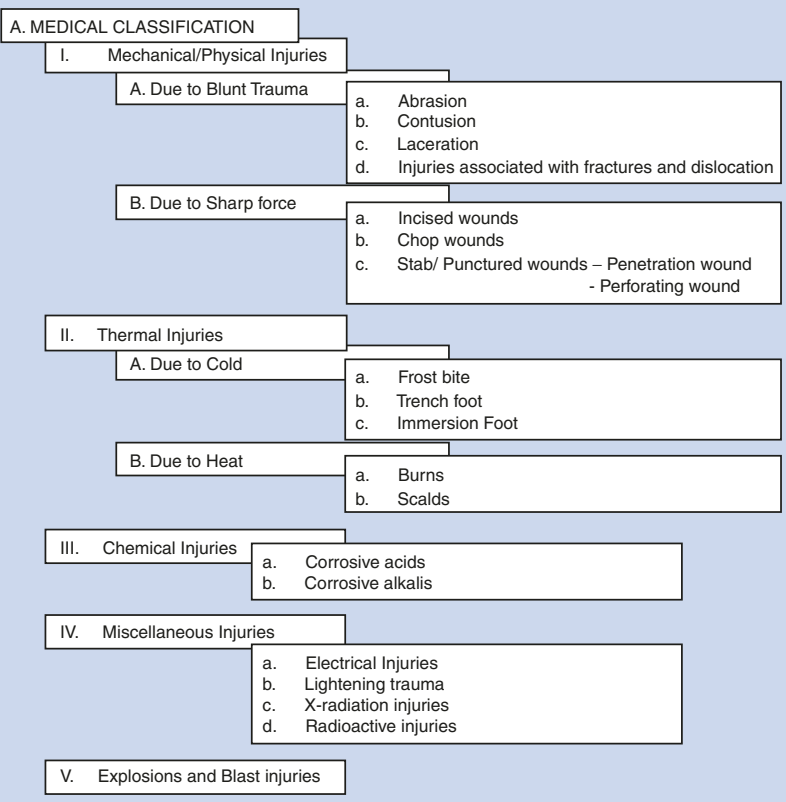

B. LEGAL CLASSIFICATION

a. Simple injuries

b. Grievous injuries Dangerous injuries

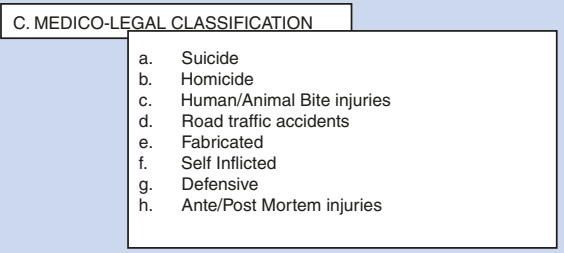



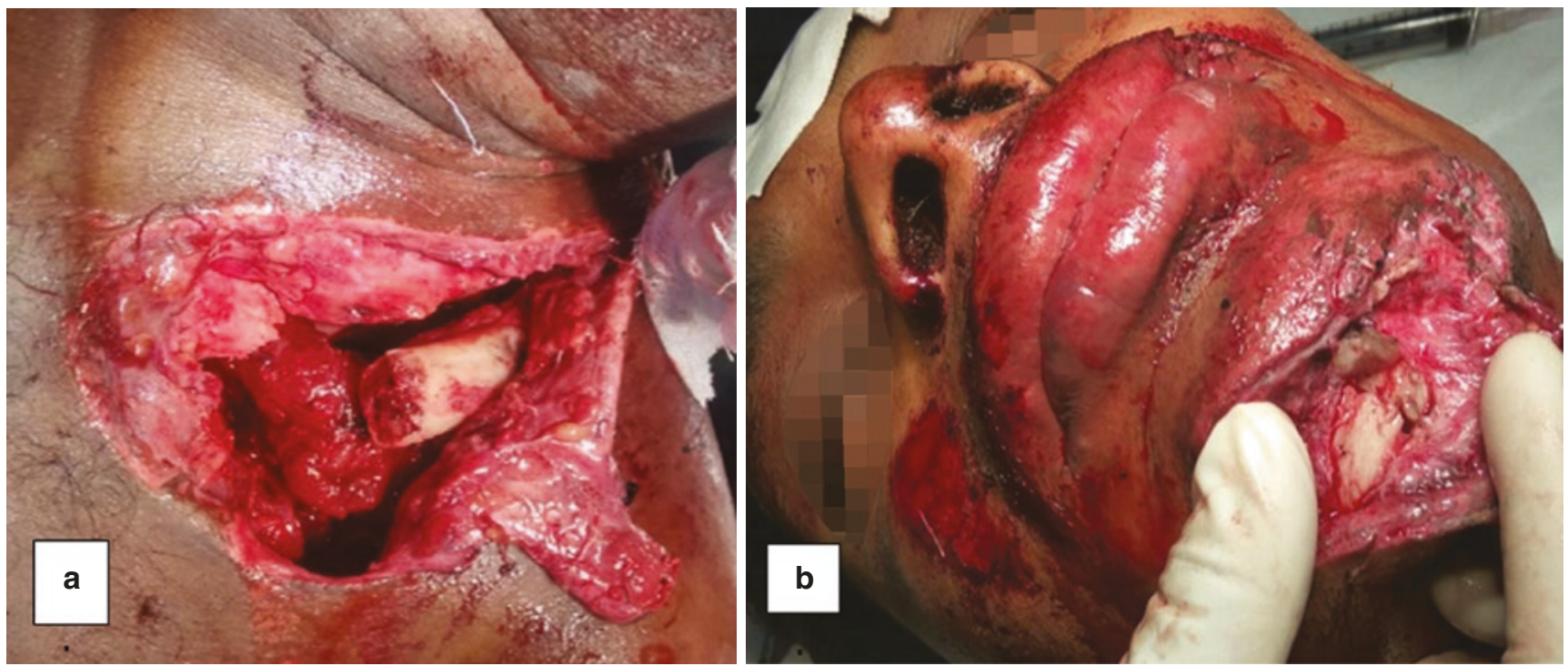

(C)Association of Oral and Maxillofacial Surgeons of India

Fig. 49.1 (a) Showing open wound where fractured left clavicle is visible from the wound surface. (b) Open wound of maxillofacial region where underlying mandible is visible

(C) Based on the communication of the injury with the external environment

Closed wound: Only the underlying tissue and/or structures are damaged without breaking the skin. Examples of closed wounds include hematomas, contusions, and crush injuries. These types of wounds are not contaminated and, hence, heal on their own without any sequelae.

Open wounds: There is a break in the skin, which exposes the underlying structures to the external environment. Open wounds include simple and complex lacerations, avulsions, punctures, abrasions, accidental tattooing, and retained foreign body with a tendency to heal with scarring. These injuries require extensive exploration and debridement followed by a course of antibiotic regimen for uneventful healing (Fig. 49.1).

(D) According to the facial subunit(s) involved. The major esthetic subunits on the face are the scalp, forehead, nose, periorbital region, cheek, perioral region, auricle, and neck [4].

These major facial esthetic subunits are further divided into smaller subunits by location. The individual subunits must be reconstructed individually one by one in order to attain good esthetics (Fig. 49.2).

(E) Based on additional injuries to the related structures

(a) Injuries to nerve-The nerve injuries are most commonly encountered in cases of open wounds.
The nerve injuries are further classified into neuropraxia, axonotmesis, and neurotmesis (Seddon's classification of nerve injuries [5]). Sunderland [6] further revised this classification of nerve injuries based on the histologic degree of nerve damage. There should be careful evaluation of sensory and motor components of the nerves in the involved region for proper treatment. The most commonly encountered nerve injuries in maxillofacial region are the facial nerve and trigeminal nerve.

(b) Injuries to arteries and veins-The face is a highly vascular region where even a small injury leads to significant bleeding. Any wound in maxillofacial region should be attended in emergency setting at the earliest due to chances of injury to the extensive vascular network which necessitates hemostasis.

(c) Injuries to parotid duct-Seen in cases of deep lacerations on cheek at the region of parotid duct. If undiagnosed and untreated, this injury can lead to cumbersome sequelae of parotid fistula. Parotid duct injury is suspected if the laceration involves an imaginary line joining the tragus of the ear to the upper lip. In such cases, exploration is performed to evaluate the injury, and suturing should be done using a stent to establish patency of the duct.

(F) Rank and Wakefield classification [7] of wounds

(a) Tidy wounds-The wounds that are inflicted by sharp instruments like surgical blades and contain 


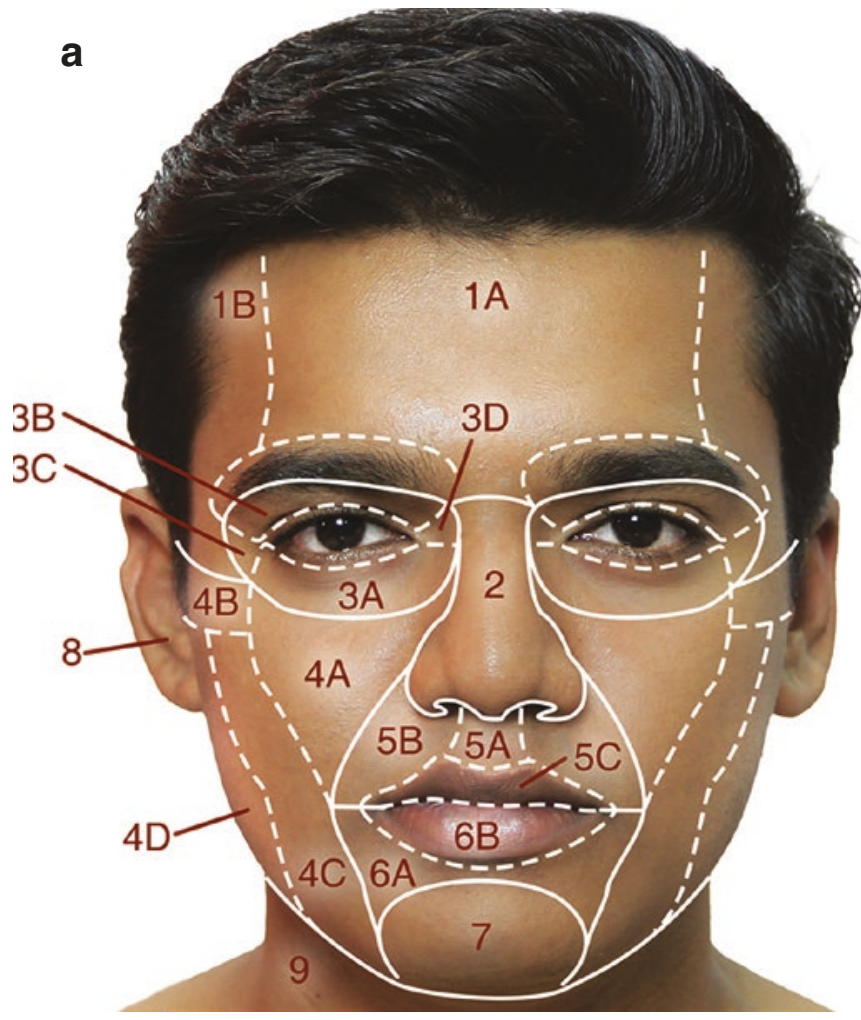

CAssociation of Oral and Maxillofacial Surgeons of India

Fig. 49.2 Various facial esthetic subunits (Also see Fig. 86.3 in this book)

no devitalized tissue are called tidy. These wounds are closed primarily. Examples are surgical incisions, cuts from glass, and knife wounds.

(b) Untidy wounds-Untidy wounds result from crushing, tearing, avulsion, vascular injury, or burns and contain devitalized tissue. Such wounds must be managed by wound excision. The devitalized tissue is excised, and the untidy wound is converted into the tidy wound before proper closure is achieved. The chances of infection are high if inadequately managed.

(G) CDC classification of surgical wounds

A surgical wound is a wound created by incisions and placement of drains during surgeries.

Surgical wounds can be classified into four different categories depending on the bacterial load, the risk of infection, and where the wound is located on the body.

Class I: Clean wounds. They show no signs of infection or inflammation. They often involve the eye, skin, or vascular system. It is often due to nonpenetrating (blunt) trauma.

Class II: Clean-contaminated wounds. Although the wound may not show signs of infection, it is at an increased risk of becoming infected because of its

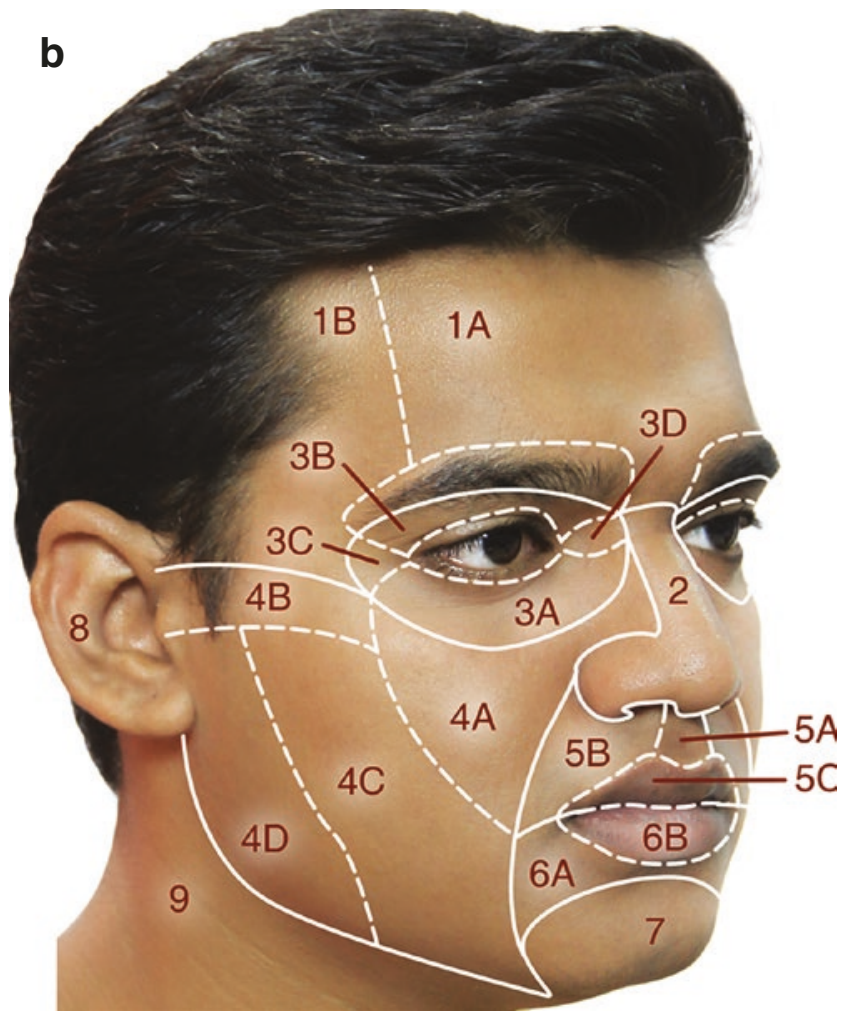

location. For example, surgical wounds in the respiratory tract like oropharynx and gastrointestinal tract may be at a high risk of becoming infected.

Class III: Contaminated wound. A surgical wound in which an outside object has come into contact with the skin and has a high risk of infection. For example, a gunshot wound may contaminate the skin around where the surgical repair occurs.

Class IV: Dirty-contaminated or infected wounds.

The wounds that have been exposed to fecal material and have a high bacterial load.

This wound classification guides in choosing appropriate treatment as well as helps in predicting post-repair form and function.

\subsubsection{Common Soft Tissue Injuries}

The common clinical presentation of soft tissue injuries included abrasions, contusions, and lacerations.

1. Abrasions-(also known as gravel rash) (Fig. 49.3)—-It is destruction of the superficial layer of skin only. It is caused by frictional forces that are light enough to erode only the superficial layer of epidermis. It can be scratches 


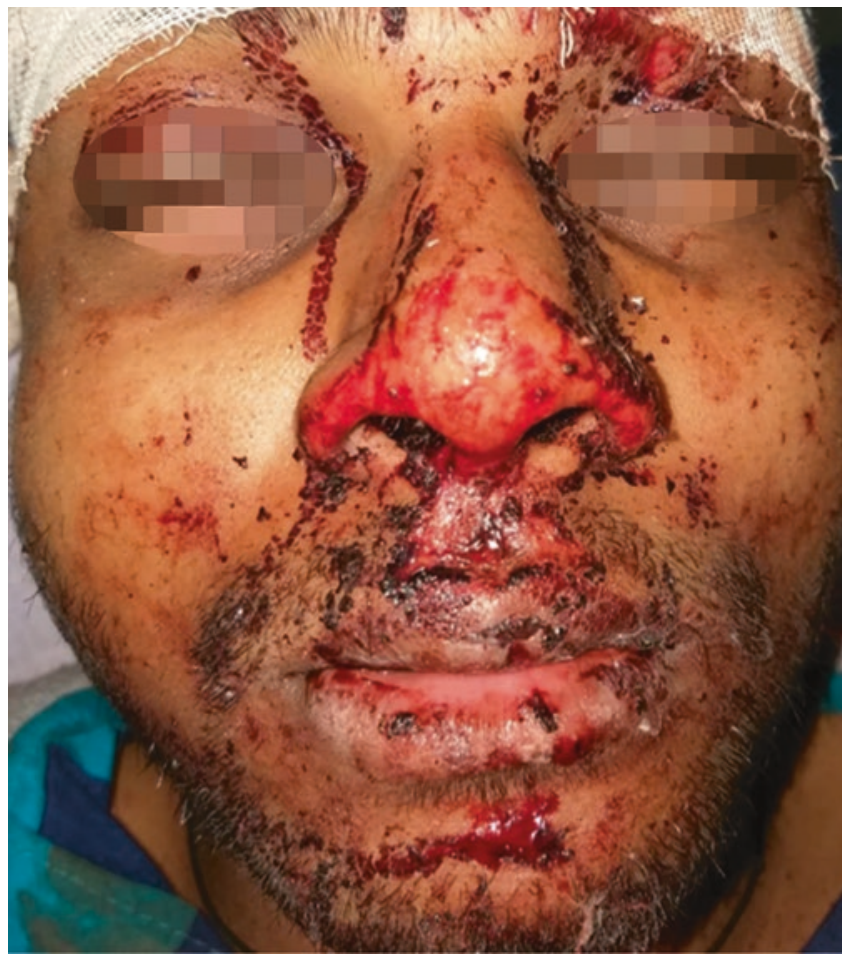

CAssociation of Oral and Maxillofacial Surgeons of India

Fig. 49.3 Showing multiple abrasions over face involving the supraorbital region, nose, upper lip, and chin

or linear type of abrasion, graze or sliding abrasion, pressure abrasions, and impact abrasions.

The healing of abrasions takes place from the periphery of the wound towards the center by new growth of epithelial cells. The wound is bright red in color for the first 12-24 h due to extravasation of blood which dries up to form a red scab. After 2-3 days, a reddish-brown scab is formed. After 4-7 days, epithelium grows and covers the defect under the scab, which gives it a dark brown to brownish-black appearance. After 7 days, the scab dries and ultimately falls off, leaving depigmented bright pinkish area underneath, which attains its normal pigmentation gradually over a period.

2. Contusions (bruising) (Figs. 49.4 and 49.5)—This is effusion of blood into the tissues, due to the rupture of small blood vessels at the site of impact. There is no destruction of the superficial layer of skin. The subtypes are (a) intradermal, (b) subcutaneous, and (c) deep.

A bruise heals by disintegration of extravasated blood. The red cells in the wound are hemolyzed, and the hemoglobin molecule is broken down into hemosiderin, hematoidin, and bilirubin by the action of enzymes.

This type of injury demonstrates a change in the color of the wound according to the time lapsed after injury: red at the time of injury, blue within few hours to 3 days, and

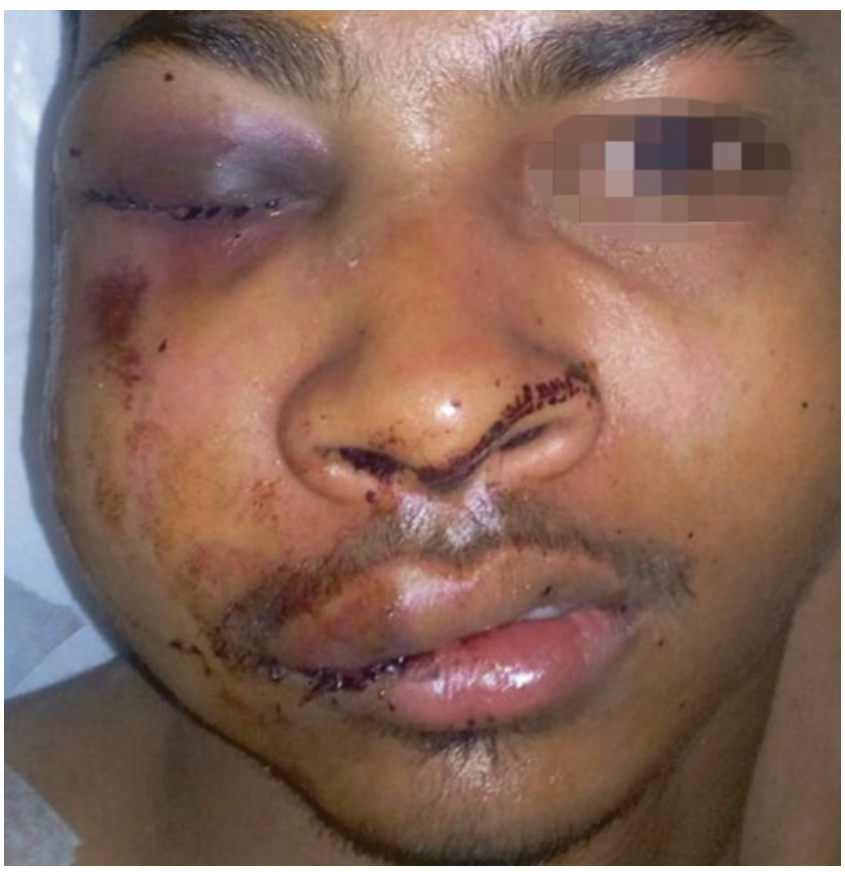

CAssociation of Oral and Maxillofacial Surgeons of India

Fig. 49.4 Showing contusion wound over right cheek and periorbital ecchymosis of the right eye. The color changes can be appreciated intraorally

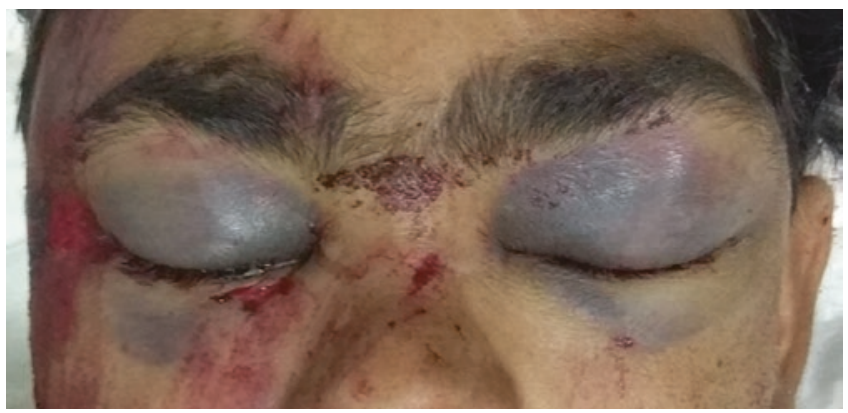

CAssociation of Oral and Maxillofacial Surgeons of India

Fig. 49.5 Showing bilateral periorbital ecchymosis (raccoon eyes)

bluish-black to brown color due to deposition of hemosiderin from the extravasated RBCs, by the 4th day. In 5-6 days, the wound appears greenish due to disintegration of hemoglobin to hemosiderin. Between 7 and 12 days, the wound appears yellow due to the presence of bilirubin which is the final disintegrated product from hemoglobin. The wound appears normal by 2 weeks. The various factors affecting the color of contusion include the depth of the bleeding, amount of extravasated blood, and overlying skin color.

3. Lacerations - It is the tear or split of skin, mucous membrane, muscle, or internal organs produced by the application of blunt force to a broad surface area, which 


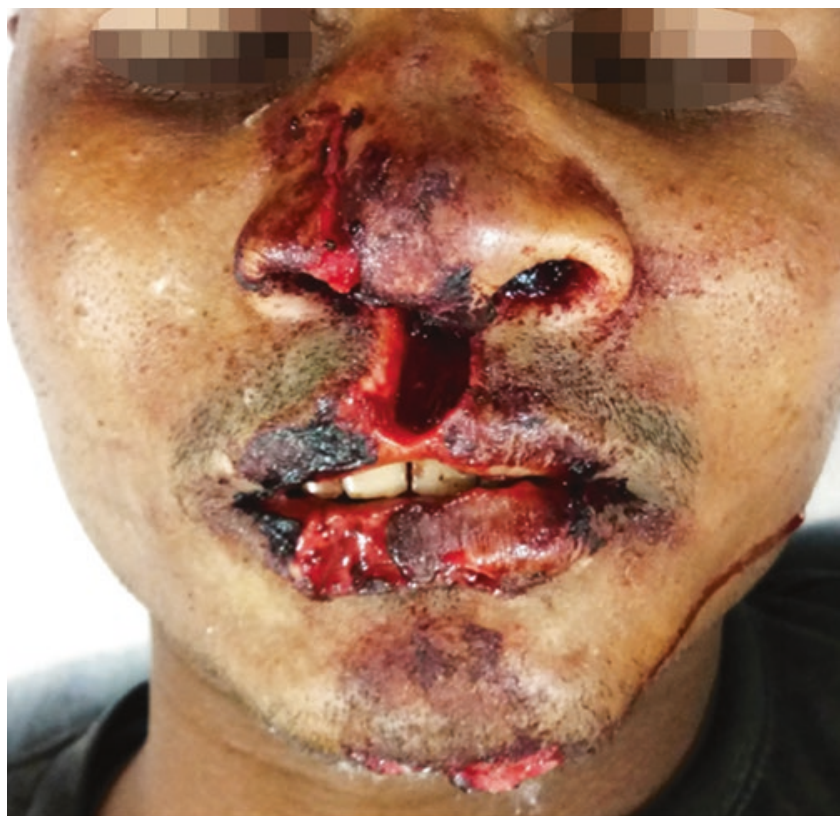

CAssociation of Oral and Maxillofacial Surgeons of India

Fig. 49.6 Showing split lacerated wound over the nose, columella, lower lip, and chin

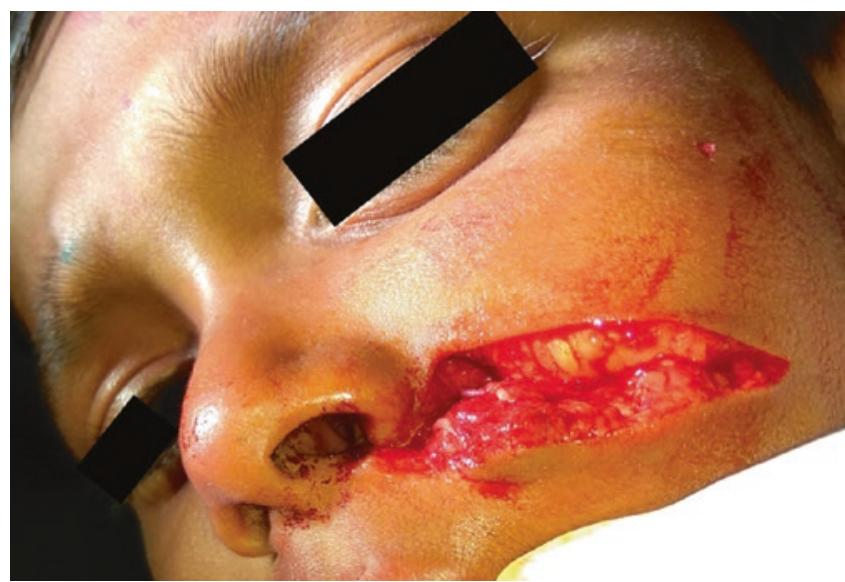

CAssociation of Oral and Maxillofacial Surgeons of India

Fig. 49.7 Cut laceration having sharp clean cut edges

crushed or stretched tissues beyond the limits of their elasticity. They can be split lacerations (Fig. 49.6), stretch lacerations, shearing lacerations, and cut lacerations (Fig. 49.7).

4. Incised wounds-The wound is longer than it is deep. It is caused by the pressure and friction of any sharp object against the soft tissues (Fig. 49.8).

5. Chop wounds (slash wounds) - They are deep bigger wounds with gaping caused by a blow with the sharpcutting edge of a heavy weapon, like an axe or chopper.

6. Stab or punctured wounds-Produced when the force is delivered along the long axis of a narrow or pointed

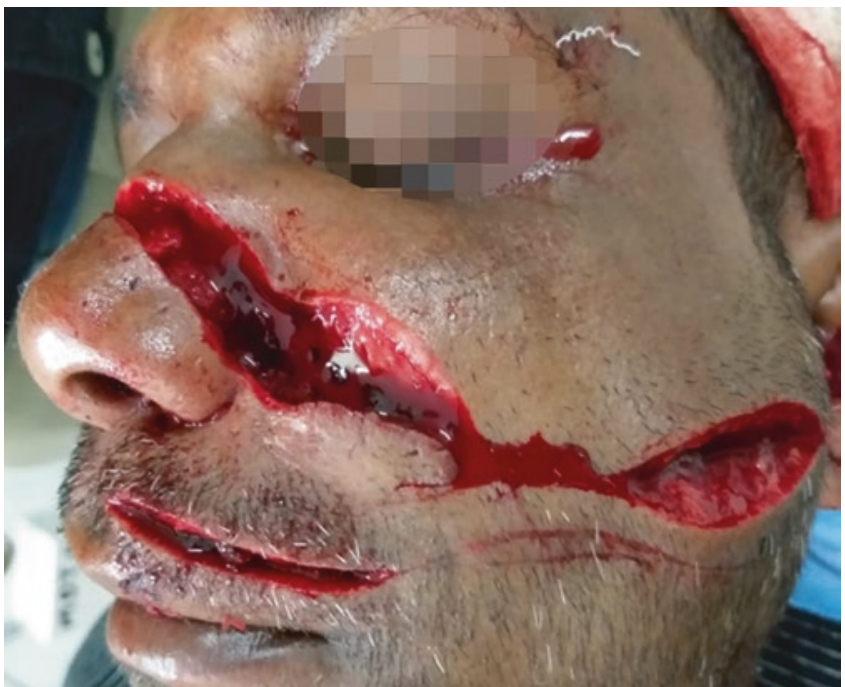

CAssociation of Oral and Maxillofacial Surgeons of India

Fig. 49.8 Showing incised wound extending from dorsum of the nose till pre-auricular region; caused by knife in a case of assault

object, such as knife, sword, chisel, scissors, nail, needle, spear, arrow, screw driver, etc. into the depths of the body. This type of wound is deeper than its length and width. These can be of the following types:

(a) Penetrating wounds-When an object pierces the skin and enters a cavity of body or a viscus creating a localized path of entry leaving it an open wound (Fig. 49.9). In head and neck region, this type of injuries should be assessed for upper airway and bleeding as direct trauma to vital structures occurs along with facial bone fractures. Careful exploration of the wounds should be performed, and any impacted debris should be removed before closure.

(b) Perforating wounds or through-and-through puncture wounds-Produced when the object enters the body at one surface and exits at another surface without causing much tissue loss. The wound of entry is larger with inverted edges, and the wound of exit is smaller with everted edges. They are considered to be sterile wounds (Fig. 49.10).

7. Crush injury-A crush injury typically occurs when the body part is crushed between two heavy blunt objects. Most severe trauma cases will have this type of injury. Crush injuries have ragged edges, varying amounts of devitalized tissue, and, sometimes, tissue loss.

8. Avulsion injuries-These involve significant tissue loss. Avulsion can be considered a very severe form of abrasion, wherein all layers of skin are torn off and the underlying structures are grossly exposed. The term avulsion can also mean complete loss of a small body part such as eyelid, fingertip, part of ear, etc. 

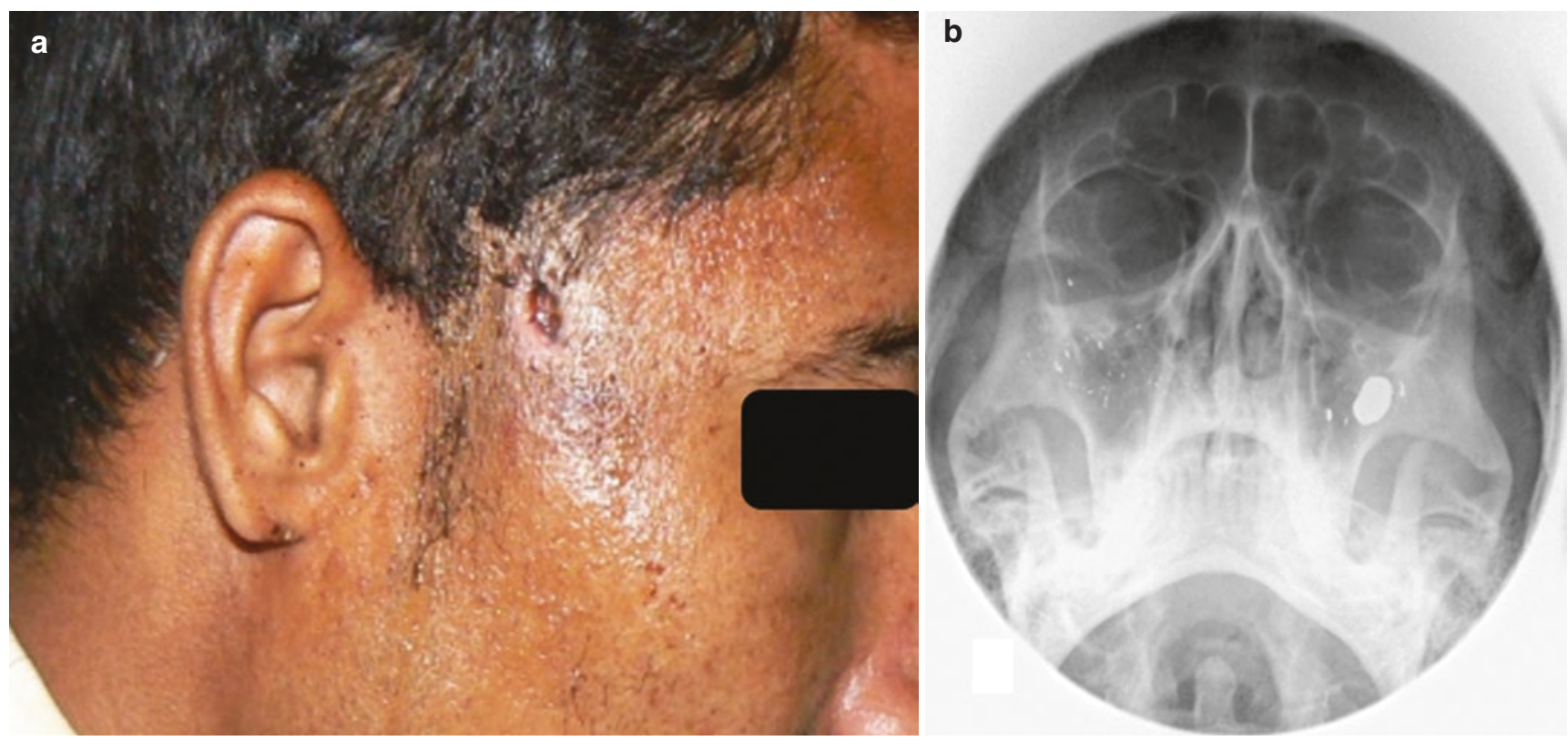

CAssociation of Oral and Maxillofacial Surgeons of India

Fig. 49.9 Showing penetrating wound. (a) Only the entry site is seen over the right temporal region. (b) The object remains dislodged within the body cavities
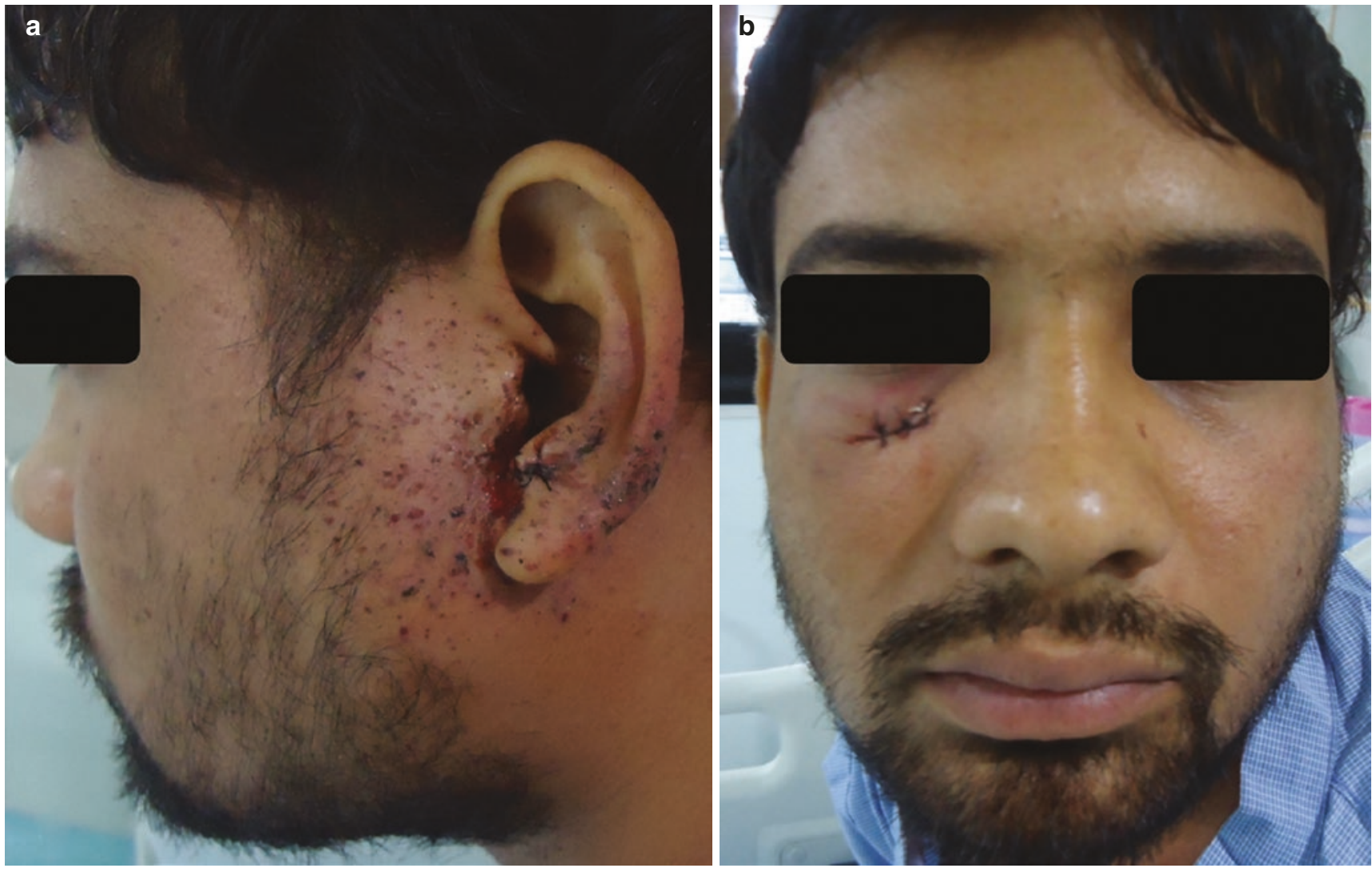

CAssociation of Oral and Maxillofacial Surgeons of India

Fig. 49.10 Showing gunshot wound injuries. (a) Picture showing entry wound over pre-auricular region. (b) Showing exit wound over right infraorbital region on opposite side 
9. Burn injuries-Burns are injuries to tissues caused by heat, friction, electricity, radiation, or chemicals. Most burns are from hot objects (including fluids) and fire. Burns cause severe skin damage where the cells die. Burns are highly painful injuries which require specific treatment as distinct from other injuries depending on the degree of burn.

The clinical presentation of burns depends largely on the depth of injury. Superficial burns (first degree) are confined to the epidermis. They are characterized by severe pain, dryness, and redness of skin. Superficial partialthickness (second degree) burns extend into the papillary dermis. The skin is moist and red and blanches with pressure. Blisters are common in this type of injury. Deep partial-thickness burns extend into the reticular dermis. The skin is dry and appears yellow or white with minimal blistering. Full-thickness burns extending to the entire depth of dermis are classified as 3rd degree. These are very severe injuries. The skin is stiff, leathery, and brown, but pain is not a common feature. Fourth-degree burns involve charring of skin and affect the deeper structures like fat and muscle. The skin is dry, black, and painless.

\subsection{Initial Evaluation and Assessment}

All trauma patients should be assessed and managed initially according to the principles of Advanced Trauma Life Support. Soft tissue injuries of the head and neck region can be accompanied by significant swelling and bleeding leading to airway compromise. The patient also should be assessed for associated ophthalmologic, intracranial, and cervical spine injuries.

\subsection{History and Examination}

Once the patient has been evaluated for life-threatening injuries and stabilized as necessary, a thorough and focused history and physical examination of the head and neck should be performed. History includes timing and mechanism of injury.

Early treatment of soft tissue injuries is associated with optimal esthetic outcomes. Determining the mechanism of injury may help the surgeon in managing the wounds with special consideration. For example, crush injuries may result in a larger area of compromised tissue than appreciated on initial examination. Tissue that appears healthy initially may subsequently necrose and may require serial debridement.

The site(s), depth, and nature of all wounds should be noted. Presence of nonviable tissue, gross contamination, and any foreign body like dirt and debris are important to discern.
Palpation helps to identify the presence of underlying bony injuries. Palpation can be done through the open wound itself.

\subsection{Management of Soft Tissue Injuries}

The principles of management of soft tissue injuries include the control of bleeding, copious irrigation of the wound, debridement of devitalized tissue, and removal of foreign bodies before closure.

(a) Control of bleeding-Blood loss is minimized by applying local pressure using hands and pressure dressings. The wound should be examined thoroughly with suction, irrigation, and meticulous dissection to identify the offending vessel, if any. If local pressure fails to achieve hemostasis, local hemostatic agents can be used. Local anesthesia with adrenaline helps in control of pain as well as bleeding through its vasoconstrictive action. If generalized oozing is still present which is hampering the ability of a surgeon to close the wound, systemic measures like injectable vitamin $\mathrm{K}$, tranexamic acid, or ethamsylate can be given, provided the blood investigations (INR, BT, CT) are within normal limits.

(b) Copious irrigation serves to dilute and wash out the contamination present in a wound. All grossly contaminated wounds should be copiously irrigated with sterile saline. The fluids may be warmed to $37{ }^{\circ} \mathrm{C}$ to promote cellular activity. The cleanser should be nontoxic and have a neutral $\mathrm{pH}$. Alkaline soaps are best avoided. Antiseptics are generally not recommended for cleansing. They are applied on the wound after wound cleansing. The most commonly used antiseptic is Povidone-iodine $10 \%$ solution. An alternative solution for this purpose is Cetrimide $15 \%$ in combination with chlorhexidine gluconate $1.5 \%$.

(c) Broad-spectrum antibiotic prophylaxis is warranted in grossly contaminated wounds and bite wounds and in immunocompromised patients.

(d) Tetanus vaccination [8]—Prevention of the local wound infection especially in crushed injuries, contaminated wounds, and bite wounds is a main concern. Tetanus prophylaxis in wound management is required as per the accepted international protocols.

(e) Wound excision (also known as wound debridement or toileting of the wound) - Serial debridement of contaminated and untidy wounds done to remove all the necrotic tissues like devitalized muscles, tendons, and fascia and comminuted bony fragments that have lost the soft tissue cover of periosteum and are hanging within the wound, in order to aid in uneventful and optimum healing. The blunt contused margins of skin are also 


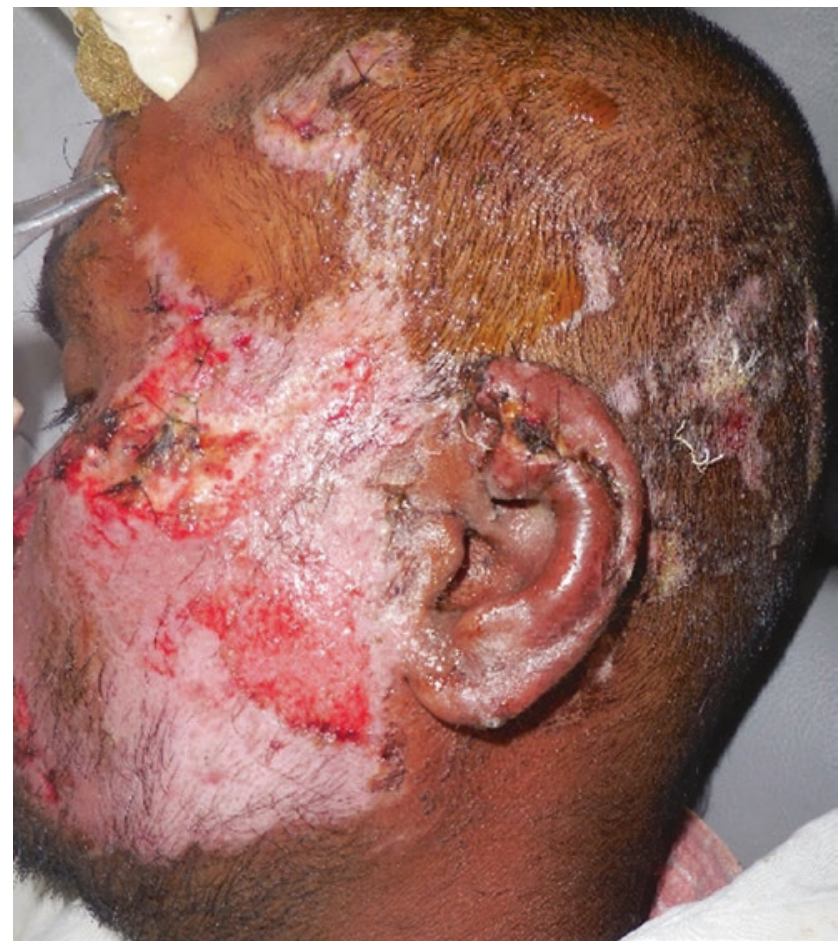

CAssociation of Oral and Maxillofacial Surgeons of India

Fig. 49.11 Showing wound excision and serial debridement of an extensive untidy wound gradually healing secondarily excised using sharp scissors, and the wound margins are freshened up. The toilet of any wound should be done in a systematic layer-wise manner from superficial to deep (Fig. 49.11).

(f) Closure-Ideally, facial soft tissue injuries should be closed as early as possible. Primary closure of a wound should be completed within 8 h of injury when possible [9]. Early intervention and closure decreases the risk of infection as well as optimizes the functional and cosmetic result. Basic principles of suturing should be met, which include precise approximation and eversion of the skin edges, avoidance of excessive tension, and layerwise closure to prevent dead space and fluid accumulation.

If gaping of the lacerated margins or tissue loss is present that cannot be closed primarily, the tissue can be managed by regular dressing and allowed to heal secondarily. Revision surgeries to improve esthetics and function are performed after minimum of 9 months.

(g) Reconstruction [10]-Done in cases of extensive degloving injuries. There are several options for soft tissue reconstruction using flaps. Starting from local, regional, distant flaps and free microvascular flaps, depending on the type, location, and extent of the injury (Box 49.2).

\section{Box 49.2 Reconstructive Options for the Head and Neck Region}

\section{CLASSIFICATION SCHEME OF VARIOUS RECONSTRUCTIVE FLAPS}

\begin{tabular}{|c|c|}
\hline & Based on CIRCULATION \\
\hline & $\begin{array}{l}\text { Axial - flap with one } \\
\text { blood vessel. Further } \\
\text { classified as } \\
\text { fasciocutaneous, } \\
\text { musculocutaneous, } \\
\text { venous and direct. E.g. - } \\
\text { Radial forearm flap, } \\
\text { nasolabial flap, submental } \\
\text { flap etc. }\end{array}$ \\
\hline & $\begin{array}{l}\text { Random - multiple } \\
\text { random tributes of } \\
\text { small vessels. }\end{array}$ \\
\hline
\end{tabular}

\begin{tabular}{|l|}
\hline According to SOURCE OF HARVEST \\
\begin{tabular}{|l}
\hline a. Local - area adjacent to the \\
wound \\
b. Regional - Same region e.g. - \\
head and neck \\
c. Distant - Region away from the \\
wound \\
d. Free Flaps - Flaps having their \\
own blood supply, connected to \\
the defect using microvascular \\
technique. \\
\hline
\end{tabular} \\
\hline
\end{tabular}

\begin{tabular}{|l|}
\hline Based on the MODE OF TRANSFER of flap \\
\hline a. Rotational - a semicircular type of \\
flap pivoting onto the defect. \\
b. Transpositional - flap that moves \\
laterally around the adjacent defect. \\
c. Advancement - Flap moved forward \\
into the wound defect. E.g.. -VY flap \\
d. Interpolational - the flap moved \\
laterally into the defect but not \\
adjacent. Undermined to reach the \\
area.
\end{tabular}
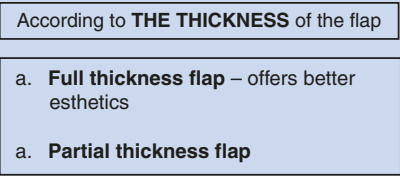

Based on COMPOSITION of the flap

Dermal
b. Muscle
c. Fascia
d. Tendon
e. Bone
t. Various combinations

\subsection{Wound Dressings}

Wound dressings are sterile pads used to cover the wounds. Lister [11] introduced antiseptic dressings by soaking gauze in carbolic acid. The dressings should be clean and provide a warm and moist environment for the successful wound healing. The dressings should be frequently changed in order to keep the wound free from bacterial load. Antibacterial ointments must be applied over the wound to keep it lubricated and free from bacteria. The dressings are selected on the basis of two concepts: occlusion and absorption. The reasons for placing a wound dressing are enumerated in Box 49.3. 


\section{Box 49.3 Purposes of Dressings}

Purposes of applying dressings over wounds

(i) Protection the wound from elements of nature

(ii) Prevention of bacterial contamination

(iii) Application of compression where required

(iv) Absorption of exudate

(v) Facilitation of hemostasis

(vi) Prevention of further inadvertent trauma to wound site

In selected cases, the dressing is modified to achieve additional purposes such as

(vii) Relief of pain

(viii) Application of topical antibiotic

(ix) Removal of slough and foreign bodies from the wound

Studies [12] have demonstrated that the rate of epithelialization under a moist occlusive dressing is twice that of a wound that is left uncovered and allowed to dry. An occlusive dressing provides a mildly acidic $\mathrm{pH}$ and low oxygen tension on the wound surface, which is conducive for fibroblast proliferation and formation of granulation tissue.

However, wounds that produce significant amounts of exudate or have high bacterial counts require a dressing that is absorptive and prevents maceration of the surrounding skin. These dressings also need to reduce the bacterial load while absorbing the exudate produced. Placement of a pure occlusive dressing without bactericidal properties would allow bacterial overgrowth and worsen the infection.

The various types of dressings [13] can be enumerated as in Table 49.1.

\subsection{Other Therapies}

1. Hyperbaric oxygen therapy-uses oxygen as a drug and the hyperbaric chamber as a delivery system to increase PO2 at the target area. It involves inhalation of $100 \%$ oxygen at 1.9-2.5 atm, for sessions of 90-120 min each. Treatments are given once daily, five to six times per week and should be given as an adjunct to surgical or medical therapies. Clinical evidence of wound improvement should be noted after 15-20 treatments.

Table 49.1 Types of wound dressing materials

\begin{tabular}{|c|c|c|c|}
\hline $\begin{array}{l}\text { Kind of } \\
\text { dressing }\end{array}$ & Examples & Properties & Indications \\
\hline \multirow[t]{2}{*}{ Protective } & Gauze & $\begin{array}{l}\text { Inexpensive, readily available } \\
\text { Highly permeable and nonocclusive } \\
\text { Dry dressing_can stick to the wound if used } \\
\text { primarily }\end{array}$ & $\begin{array}{l}\text { As secondary dressing over another } \\
\text { material }\end{array}$ \\
\hline & $\begin{array}{l}\text { Polymeric films (Opsite, } \\
\text { Tegaderm) }\end{array}$ & $\begin{array}{l}\text { Transparent, waterproof dressing } \\
\text { Semi-permeable, thin, highly elastic }\end{array}$ & Surgical incisions \\
\hline \multirow[t]{2}{*}{ Absorbent } & Hydrogels & $\begin{array}{l}\text { Mostly contain water } \\
\text { Provide a moist and cool environment }\end{array}$ & $\begin{array}{l}\text { Wounds with mild exudates } \\
\text { Not for heavily exudating or infected } \\
\text { wounds }\end{array}$ \\
\hline & Hydrocolloids & $\begin{array}{l}\text { Composed of methylcellulose, pectin, and } \\
\text { gelatin } \\
\text { Absorb fluids and convert them into a gel that } \\
\text { covers the wound } \\
\text { Provides pain relief as the gel covers nerve } \\
\text { endings }\end{array}$ & $\begin{array}{l}\text { Light to heavily exuding wounds such } \\
\text { as burns } \\
\text { Must not be used on infected wounds }\end{array}$ \\
\hline \multirow[t]{3}{*}{ Bioactive } & \multirow[t]{2}{*}{ Antimicrobial dressings } & $\begin{array}{l}\text { Soft, paraffin dressing impregnated with } \\
\text { chlorhexidine (Bactigras) or framycetin } \\
\text { (Sufratulle) } \\
\text { Actively prevent bacterial contamination }\end{array}$ & $\begin{array}{l}\text { Flat, shallow wounds such as skin graft } \\
\text { donor sites, superficial burns, and } \\
\text { abrasions }\end{array}$ \\
\hline & & $\begin{array}{l}\text { Require a secondary dressing over it } \\
\text { Scarlet Red, a relatively nonocclusive dressing } \\
\text { that is impregnated with } \\
O \text {-tolylazo- } O \text {-tolylazo- } \beta \text {-naphthol } \\
\text { Xeroform-hydrophobic dressing containing } \\
3 \% \text { bismuth tribromophenate in a petrolatum } \\
\text { base, which helps mask wound odors and has } \\
\text { antimicrobial activity against Staphylococcus } \\
\text { aureus and Escherichia coli }\end{array}$ & Skin graft harvest sites in burn care \\
\hline & Collagen dressings & $\begin{array}{l}\text { Activate matrix metalloproteinases and promote } \\
\text { new collagen formation }\end{array}$ & $\begin{array}{l}\text { Chronic non-healing wounds } \\
\text { Burn wounds }\end{array}$ \\
\hline
\end{tabular}


Mechanism of action-HBO therapy can increase tissue $\mathrm{PO} 2$ ten times higher than usual. The higher $\mathrm{PaO} 2$ is sufficient to supply the tissue with all its metabolic requirements even in the absence of hemoglobin. This elevated level lasts for 2-4 $\mathrm{h}$ after termination of HBO therapy and induces synthesis of endothelial cell NO synthase as well as angiogenesis. Oxygen stimulates angiogenesis, enhances fibroblast and leukocyte function, and normalizes cutaneous microvascular reflexes, thus aiding in healing of chronic, complicated, non-healing wounds.

2. Negative pressure-assisted wound therapy-Argenta [14] and associates originally described the use of negative pressure to assist in wound closure in 1997. By applying subatmospheric pressure to wounds, they demonstrated removal of chronic edema, an increase in local blood flow, and stimulation of granulation tissue. This technique may be used on acute, subacute, and chronic wounds. The wound is filled with a foam substance. A drainage tube is inserted into, or laid on, the foam, and the part is then covered with impermeable film. Suction is applied at around $125 \mathrm{mmHg}$ between changes of dressing.

\subsection{Necrotizing Fasciitis}

It is a rapidly spreading necrotizing soft tissue infection, also known as flesh-eating disease. It is one of the most challenging infections faced by the maxillofacial surgeons due to its diagnosis and management. The most common bacteria responsible for the fascial necrosis are hemolytic Streptococcus and Staphylococcus.

It is foul-smelling with loss of skin and superficial subcutaneous tissue, having patchy blackish necrosis and frank pus along with the raw surface of the wound, margins of which are pale and spreading in nature. If it involves the skin of scrotum, it is known as Fournier's gangrene.

The prompt diagnosis and aggressive treatment is the key to manage this complicated condition. Removal of the offending factors like carious tooth and infected foreign material is the prime step followed by aggressive debridement and desloughing involving the normal tissue margins under the antibiotic coverage and adequate anesthesia. Once the wound is free of the active infection, showing healing margins with no evidence of pus, it is reconstructed with the skin grafts (Fig. 49.12).
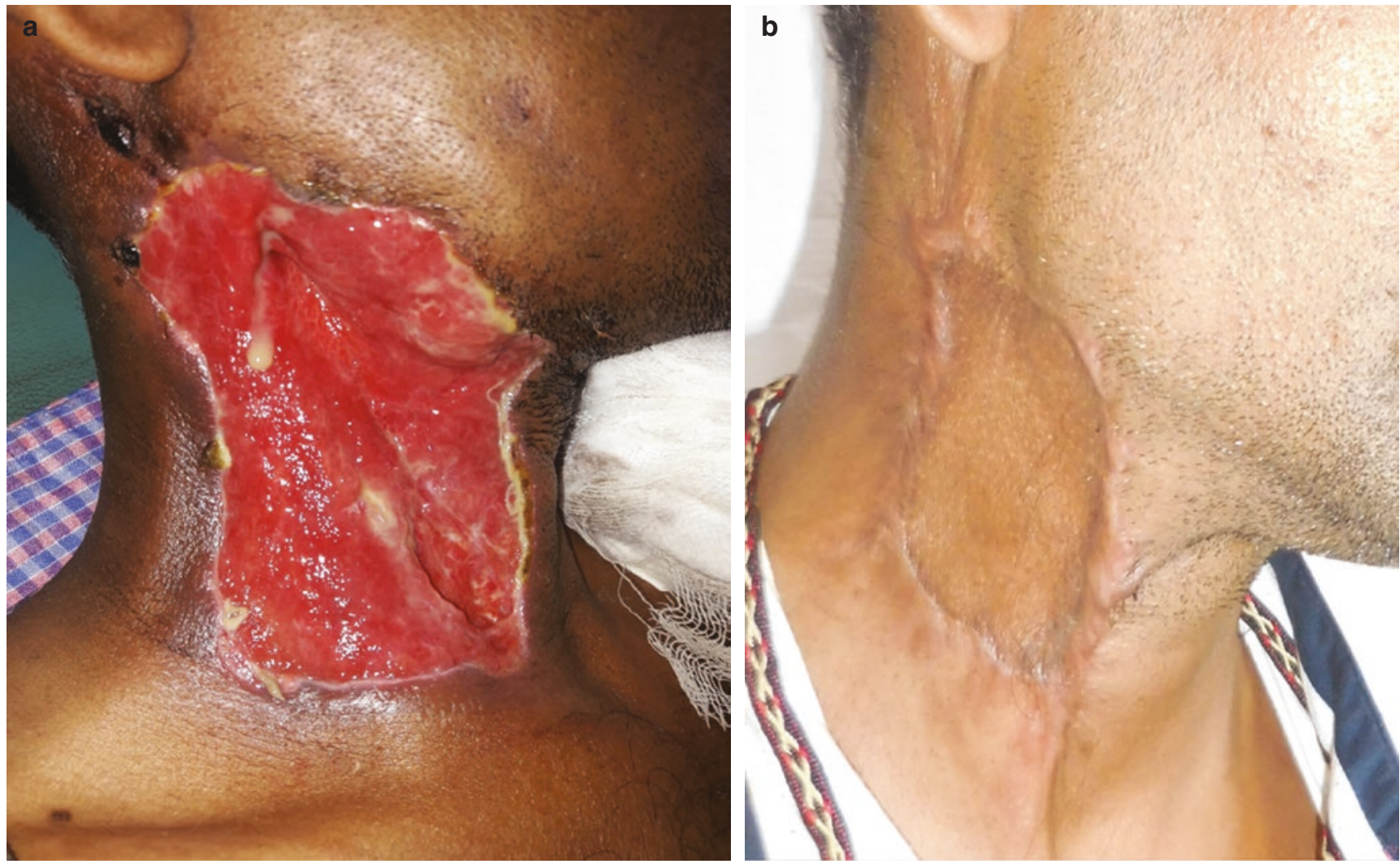

CAssociation of Oral and Maxillofacial Surgeons of India

Fig. 49.12 Depicting a case of necrotizing fasciitis of the right side of the neck due to infection from right mandibular third molar. The patient was promptly and aggressively managed by sequential debridement followed by anterolateral thigh skin graft 
Table 49.2 Phases of wound healing

\begin{tabular}{|l|l|}
\hline $\begin{array}{l}\text { Phases of wound healing } \\
\text { Inflammatory phase }\end{array}$ & Time period \\
\hline Immediate till 5th day \\
\hline Proliferative phase & Established by 5th day
\end{tabular}

Pstablished by 5th day

Maturation phase
Mechanism of healing

- Immediate vascular response

- Cellular infiltration-Polymorphonuclear leukocytes initially, followed by monocytes within $24 \mathrm{~h}$, which become dominant by the 5 th day and actively engaged in phagocytosis

- Formation of new blood vessels at the edges of wound (neovascularization)

- Synthesis of granulation tissue

- Cellular proliferation-Macrophages are preponderant

- With time, the number of fibroblasts increases that are active in synthesis of extracellular collagen and proteoglycans (collagen synthesis)

- The fibroblasts in the wound are closely followed by the endothelial buds of capillaries. The wound is filled with vascular granulation tissue containing new capillaries, fibroblasts, macrophages, and mast cells

- An intrinsic increase in the mechanical strength of the wound at the end of this phase

- Extensive remodeling as a result of a decrease in the numbers of fibroblasts and macrophages concurrent with a decrease in vascularity

- Increase in wound strength

- Formation of scar tissue

\subsection{Principles of Soft Tissue Healing}

The three phases of repair in soft tissue wounds are overlapping and include

- The inflammatory phase

- The proliferative phase

- The maturation phase (Table 49.2)

Any alteration in the local environment of the wounds or the systemic status of the patients can influence the normal process of wound healing.

\subsection{Types of Wound Healing}

The various types of wound healing include:

1. Primary intention

2. Delayed primary closure

3. Secondary intention

1. Primary intention-occurs when full-thickness wound edges are approximated shortly after the primary wound has been created. This type of closure is generally avoided in grossly contaminated wounds, in wounds that cannot be completely debrided, and in wounds where further tissue loss is anticipated as in blast injuries.

2. Delayed primary closure-Primary closure is delayed to allow host inflammatory and immune responses to control contamination. It is typically completed 3-4 days after the initial injury but depends on the particular characteristics of the wound. Serial debridements may be performed until the full extent of tissue devitalization is determined.
Table 49.3 Factors that negatively influence wound healing

\begin{tabular}{|c|c|}
\hline Local factors & Systemic factors \\
\hline Presence of foreign bodies & Smoking \\
\hline Venous insufficiency & Comorbidities like diabetes \\
\hline Ischemia/ hypoxia to & Systemic condition-malnutrition, \\
\hline tissues & chronic illness, deficiency of vitamins \\
\hline Radiation & Prolonged drug use-corticosteroids, \\
\hline Salivary contamination & cytotoxic chemotherapy \\
\hline Scarring & \\
\hline Hematoma & \\
\hline
\end{tabular}

3. Secondary intention - healing is by natural biologic processes without surgical intervention, and it usually occurs in large wounds associated with soft tissue loss or avulsion. It involves epithelialization and collagen deposition for wound healing. Contraction is the most important phenomenon in the spontaneous closure of large open wounds.

\subsection{Complications in Wound Healing}

Complications in the normal process of wound healing may occur due to presence of various local and systemic factors which exert a negative impact (Table 49.3).

One of the frequently observed complications is "abnormal wound healing" which presents in different forms such as keloids and hypertrophic scars. These are proliferative scars characterized by excessive net collagen deposition. Keloids and hypertrophic scars (Fig. 49.13) differ histologically from normal scars. The clinical appearance of the two types of scar is described in Table 49.4.

Keloids and hypertrophic scars contain collagen bundles aligned in the same plane as the epidermis. Tension 

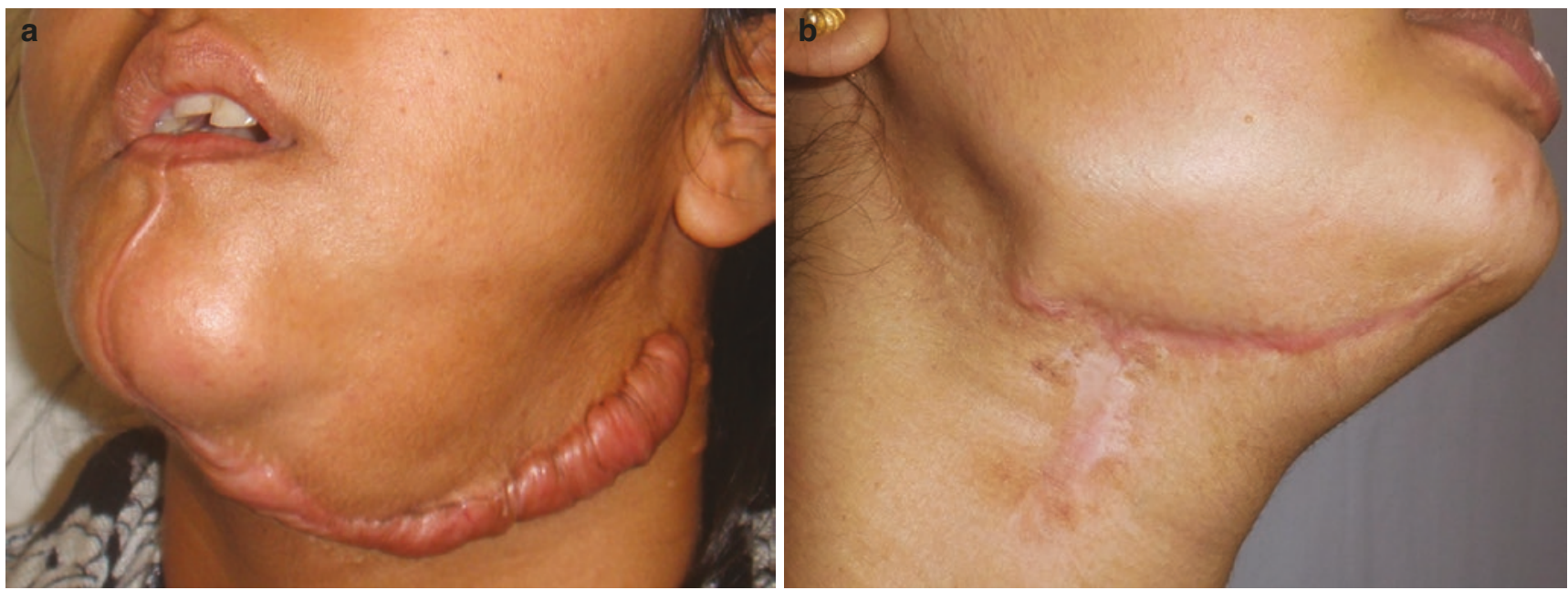

(CAssociation of Oral and Maxillofacial Surgeons of India

Fig. 49.13 Showing. (a) keloid type of scar and (b) hypertrophic scar healing

Table 49.4 Difference between keloids and hypertrophic scar

\begin{tabular}{|c|c|}
\hline Keloids & Hypertrophic scar \\
\hline Contain disorganized type I and type III collagen bundles & Primarily contain well-organized type III collagen fibers \\
\hline $\begin{array}{l}\text { The collagen bundles are thicker and form a nodelike structure in } \\
\text { the deep layer of skin }\end{array}$ & $\begin{array}{l}\text { Contain islands of aggregates of fibroblasts, small vessels, and collagen } \\
\text { fibers throughout the dermis }\end{array}$ \\
\hline $\begin{array}{l}\text { Cannot be prevented and are often refractory to medical and } \\
\text { surgical intervention }\end{array}$ & Often preventable \\
\hline $\begin{array}{l}\text { Occur above the clavicles, on the trunk, on the upper extremities, } \\
\text { and on the face }\end{array}$ & $\begin{array}{l}\text { Prolonged inflammation and insufficient resurfacing (e.g., burn wounds) } \\
\text { promote hypertrophic scarring }\end{array}$ \\
\hline $\begin{array}{l}\text { Grow beyond the borders of the original wounds and rarely regress } \\
\text { with time }\end{array}$ & $\begin{array}{l}\text { Raised scars within the confines of the original wound and frequently } \\
\text { regress spontaneously }\end{array}$ \\
\hline Appear to be genetically predisposed & $\begin{array}{l}\text { Represent a reversible hyperproliferative scar phenotype that regresses } \\
\text { when the original stimulus (skin tension, stimulatory growth factors) are } \\
\text { removed }\end{array}$ \\
\hline $\begin{array}{l}\text { First-line treatments include pressure therapy and intralesional } \\
\text { corticosteroid injections. } \\
\text { Intralesional 5-fluorouracil, bleomycin, and verapamil used } \\
\text { according to the established treatment protocols. } \\
\text { Refractory cases after } 12 \text { months of therapy should be considered } \\
\text { for surgical excision in combination with adjuvant therapy. } \\
\text { Excision alone results in a high recurrence rate of } 50-100 \% \text { and } \\
\text { enlargement of the keloid. } \\
\text { Immediate postoperative electron beam irradiation or brachytherapy } \\
\text { with iridium-192 reduces recurrence rates. }\end{array}$ & $\begin{array}{l}\text { Pressure and silicone therapy combined with selective localized } \\
\text { corticosteroid injections in resistant areas. } \\
\text { Bleomycin, 5-fluorouracil, and verapamil can be used as adjuncts to } \\
\text { corticosteroid therapy. } \\
\text { Laser therapy to reduce scar thickness, resurface scar texture, and treat } \\
\text { residual redness, telangiectasias, or hyperpigmentation. } \\
\text { Early surgery is indicated if the scar causes functional impairment. Scar } \\
\text { contracture release procedures in the neck and axilla are best performed } \\
\text { with flaps to improve functional and cosmetic outcomes. } \\
\text { Widespread large hypertrophic scars may require serial excision or tissue } \\
\text { expansion. }\end{array}$ \\
\hline
\end{tabular}

over the edges of the wound signals the formation of activated fibroblasts resulting in excessive collagen deposition.

Scars perpendicular to the underlying muscle fibers tend to be flatter and narrower, with less collagen formation than when they are parallel to the underlying muscle fibers. As muscle fibers contract, the wound edges become reapproximated when they are perpendicular to the underlying muscle and tend to gape if placed parallel to it, leading to greater wound tension and scar formation.

\subsubsection{Prevention of Hypertrophic or Keloid Scars}

The four strategies that reduce adverse scarring immediately after wound closure are:

- Layer-wise closure as to avoid gaping within the layers of the wound

- Closure without tension

- Hydration of the wound with clean dressing

- Use of pressure garments 
Postsurgical taping of the wound for 3 months can reduce scarring. Moisturizing lotions and moisture-retentive dressings (silicone sheets and gels) can reduce the thickness, discomfort, and itching and improve the appearance of the scar.

\subsection{Recent Advances in Soft Tissue Management}

1. Use of growth factors - intimate role in the regulation of all phases of wound healing, i.e., chemotaxis, proliferation, matrix synthesis, inflammation, and angiogenesis. The enhancement of soft tissue wound healing can be done by various methods. Topical application of growth factors in a vehicle or by direct seeding of cells topically on the wound can enhance healing. Placement of growth factors or cells can also be done with a fibrin sealant or glue. Use of platelet-rich plasma (PRP) by degranulation of platelets with the secretion of its contents of growth factors into the surrounding fibrin matrix or, more recently, use of tissue-engineered equivalents of skin or mucosa can provide a scaffold that enhances healing.

2. Gene and stem cell therapy-in which the gene encoding for the therapeutic growth factor or protein is directly transfected into host cells. This is a promising approach for the treatment of acute and chronic wounds.

3. Tissue engineering - In 1987, the National Science Foundation bioengineering panel defined tissue engineering as "the application of the principles and methods of engineering and the life sciences toward the development of biologic substitutes to restore, maintain, or improve function."

They include—Bioengineered Skin substitutes vis [15]

(a) Epidermal substitutes-These are autografts taken from split-thickness skin grafting or from cell line bioreactor expansion and grown in laboratory until enough tissue is produced to be transferred to the wound later.

(b) Dermal substitutes-When the wound is deep and the dermis is destroyed, epidermal substitutes are not enough to ensure wound healing. The dermis is replaced by the one manufactured in the laboratory from the patient-specific cells. This dermis is essential to maintain mechanical resistance and occlude the surface of the wound. (c) Bilayer substitutes-Integra, developed in 1981, was the first acellular bilayer and has been used successfully to treat burns and chronic wound patients.

\subsection{Conclusion}

Proper assessment and classification of soft tissue injuries is the primary step in management. Early intervention and closure of soft tissue injuries is associated with optimal functional and esthetic outcomes as well as decreases the risk of complications. The basic principles of management of soft tissue injuries include the control of bleeding, copious irrigation of the wound, debridement of devitalized tissue, and removal of foreign bodies before closure. Administration of antibiotics and tetanus prophylaxis play a vital role in management of contaminated wounds. Wound dressings are mandatory to protect wounds postoperatively and facilitate ideal healing. Soft tissue injuries resulting in loss of tissue must be reconstructed using flaps which may be local, regional, distant, or free microvascular flaps, depending on the type, location, and extent of the injury. Innovative options such as growth factors, stem cell therapy, and bioengineered skin substitutes may be considered.

\subsection{Case Scenarios}

\section{Case Scenario 1}

A 23-year-old male patient met with a road traffic accident and suffered from a perforating injury over the nose, extending to right infra-orbital region. After initial resuscitating of the patient and ruling out the head injury component, the patient was taken up for the management of soft tissue and hard tissue injuries under general anesthesia. Through the existing lacerated wound, open reduction and internal fixation was done within $48 \mathrm{~h}$ of the trauma. Simultaneously, the soft tissue closure was performed layer-wise. Closure of the muscle layer was performed followed by the subcutaneous tissue and finally the skin (Fig. 49.14a-e).

\section{Case Scenario 2}

A case scenario of a 67-year-old male patient who reported to the department of Oral and Maxillofacial Surgery. He was a victim of ballistic injury while he was working in a marketplace. The penetrating pathway of the bullet could be traced 

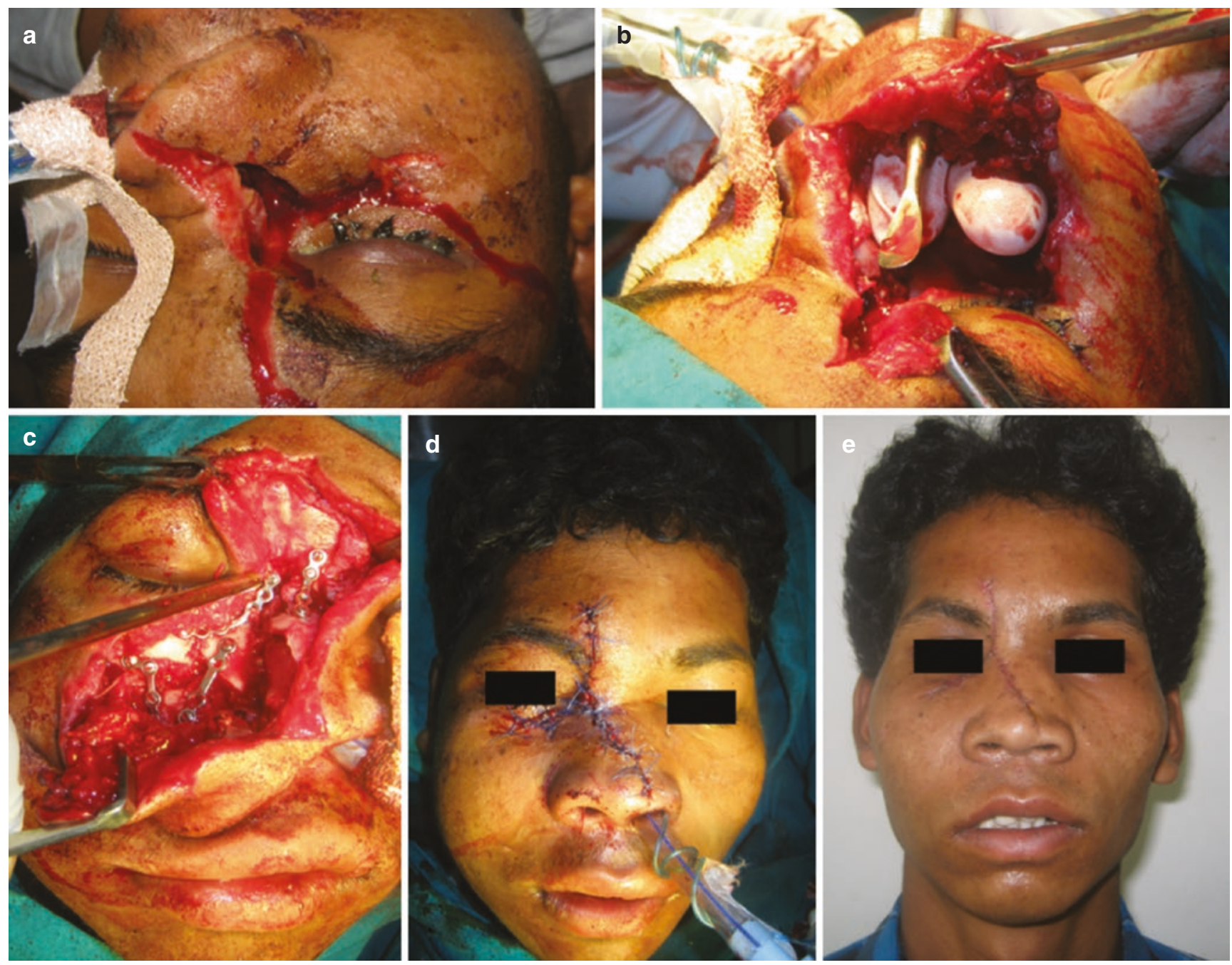

Fig. 49.14 Case scenario 1(a-e): Soft tissue management of a road traffic accident victim

having an entry site over left cheek. An extensive and careful exploration was performed in the OT under general anesthesia after the sections of 3D CT face were obtained (Fig. 49.15a-g). The comminuted fracture of the mandible was reconstructed using reconstruction plate. The bullet was found to be lodged in the carotid triangle just above the bifurcation of the common carotid artery.

Soft tissue management in such type of ballistic injuries becomes very critical. Since the bullet is a foreign material, it has to be removed from the soft tissues. The approach could either be through the entry wound but due to deep seat- ing of the bullet into the neck and proximity of vital structures, one should always think of an extensive approach. The neck dissection was carried out in this case to remove the bullet from the bifurcation of common carotid artery in as atraumatic manner as possible. Bidigital palpation is a crucial step to locate the foreign body in this region. One interesting fact about such injuries is that though they are extensive with crushed and comminuted fractures and they are sterile due to the heat generated by the velocity of the bullet along its path. Such injuries are less prone to infection. 

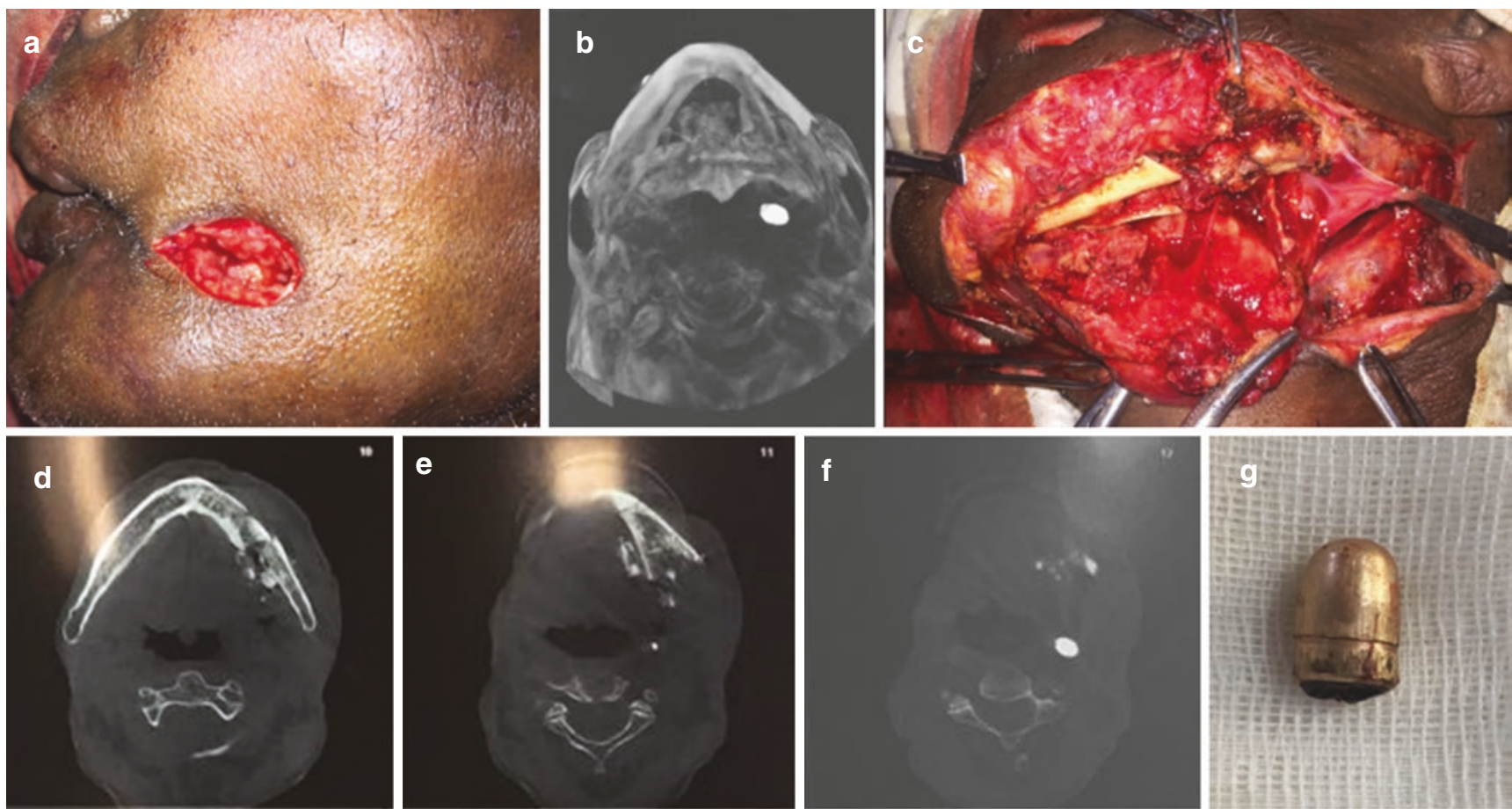

Fig. 49.15 (a-g) Case Scenario 2: Soft tissue management in a ballistic injury

Proper surgical toilet with wound irrigation followed by careful debridement remains the mainstay of treatment of all types of soft tissue injuries.

\section{References}

1. Hussain K, Wijetunge DB, Grubnic S, et al. A comprehensive analysis of craniofacial trauma. J Trauma. 1994;36:34.

2. Key SJ, Thomas DW, Shepherd JP. The management of soft tissue facial wounds. Br J Oral Maxillofac Surg. 1995;33(2):76-85.

3. Karlson TA. The incidence of hospital-treated facial injuries from vehicles. J Trauma. 1982;22:303.

4. Fattahi TT. An overview of facial aesthetic units. J Oral Maxillofac Surg. 2003;61(10):1207-11.

5. Seddon HJ, Medawar PB, Smith H. Rate of regeneration of peripheral nerves in man. J Physiol. 1943;102:191-215.

6. Sunderland S. A classification of peripheral nerve injuries producing loss of function. Brain. 1951;74:491-516.

7. Rank BK, Wakefield AR. Surgery of repair as applied to hand injuries. London: Livingstone; 1960.
8. Stefanopoulos PK, Tarantzopoulou AD. Facial bite wounds: management update. Int J Oral Maxillofac Surg. 2005;34(5):464-72.

9. Janis JE. Essentials of plastic surgery. 2nd edn. Boca Raton, FL: Quality Medical; 2014. p. 316-21, 382-5, 390, 480.

10. Frodel JL, Holt GR, Larrabee WF Jr, et al. Facial plastic and reconstructive surgery. In: Papel ID, editor. 4th edn. New York: Thieme; 2016. p. 754-65.

11. Pitt D, Aubin JM. Joseph Lister: father of modern surgery. Can J Surg. 2012;55(5):E8.

12. Morin RJ, Tomaselli NL. Interactive dressings and topical agents. Clin Plast Surg. 2007;34(4):643-58.

13. Lionelli GT, Lawrence WT. Wound dressings. Surg Clin. 2003;83(3):617-38.

14. Argenta LC, Morykwas MJ. Vacuum-assisted closure: a new method for wound control and treatment: clinical experience. Ann Plast Surg. 1997;38:563-77.

15. Greaves NS, Iqbal SA, Baguneid M, Bayat A. The role of skin substitutes in the management of chronic cutaneous wounds. Wound Repair Regen. 2013;21(2):194-210.

Open Access This chapter is licensed under the terms of the Creative Commons Attribution 4.0 International License (http://creativecommons. org/licenses/by/4.0/), which permits use, sharing, adaptation, distribution and reproduction in any medium or format, as long as you give appropriate credit to the original author(s) and the source, provide a link to the Creative Commons license and indicate if changes were made.

The images or other third party material in this chapter are included in the chapter's Creative Commons license, unless indicated otherwise in a credit line to the material. If material is not included in the chapter's Creative Commons license and your intended use is not permitted by statutory regulation or exceeds the permitted use, you will need to obtain permission directly from the copyright holder.

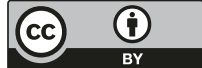

